\title{
POLA SOLIDARITAS KELOMPOK PEDAGANG ANGKRINGAN DI KOTA PONOROGO
}

Slamet Santoso dan Jusuf Harsono

Universitas Muhammadiyah Ponorogo,

E-mail : ssantoso_0219@yahoo.co.id

\begin{abstract}
ABSTRAK. Penelitian ini bertujuan untuk menemukan pola solidaritas kelompok pedagang Angkringan yang ada di Kota Ponorogo. Pendekatan yang digunakan dalam penelitian ini adalah pendekatan kualitatif dan teknik pengumpulan data menggunakan wawancara mendalam dan observasi. Berdasarkan kriteria penggolongan pedagang Angkringan, jumlah informan ditetapkan dengan menggunakan teknik purposive sampling dan untuk analisis data berproses pada bentuk induksi-interpretasi-konseptualisasi dengan menggunakan model analisis interaktif. Hasil penelitian menunjukkan bahwa: a) Jalinan solidaritas yang terjadi pada kelompok pedagang Angkringan di Kota Ponorogo berbentuk: Solidaritas antara ketua kelompok dengan para anggotanya (termasuk calon anggota), Solidaritas antara sesama anggota dalam satu kelompok, dan Solidaritas antara kelompok yang satu dengan kelompok yang lain; b) Solidaritas antara ketua kelompok dengan calon anggota kelompok lebih mengarah pada solidaritas mekanik; c) Solidaritas antara ketua kelompok dengan anggota kelompok lebih didominasi oleh solidaritas organik namun demikian solidaritas mekanik tetap berjalan walaupun hanya pada waktu tertentu; d) Solidaritas antara sesama anggota dalam satu kelompok lebih lebih didominasi oleh solidaritas organik dan untuk solidaritas mekanik hanya bersifat isidental; dan e) Solidaritas antara kelompok yang satu dengan kelompok yang lain lebih mengarah pada solidaritas mekanik.
\end{abstract}

Kata Kunci: Solidaritas Mekanik, Solidaritas Organik, Pedagang Angkringan

\section{SOLIDARITY PATTERN OF ANGKRINGAN VENDORS GROUP IN PONOROGO CITY}

ABSTRACT: This research's aim to find the solidarity pattern of Angkringan Vendors Group in Ponorogo City. The paradigm was used at this research is kualitatif perspective. This research used Depth Interview and Observation Methode. The Informans was decided by Purposive Sampling Methode and analising data by inductive-intepretative-konceptualiation and using Interactive Analyse Model. Result of this research are : a) The Pattern of Solidarity Networking at the Angkringan Vendors Group in Ponorogo City is Solidarity between the leader and members of Group (including the member candidate), Solidarity between the members each other; $b$ ) Solidarity between the leader and members candidate is Mechanic Solidarity; c) Solidarity between the leader and old members is Organic Solidarity, but at any time they have Mechanic Solidarity; d) Solidarity between members in the same group is Organic Solidarity and once in a while they have Mechanic Solidarity; and e) Solidarity between the groups each other is Mechanic Solidarity.

Key Words : Mechanic Solidarity, Organic Solidarity, Angkringan Vendors

\section{PENDAHULUAN}

Istilah sektorinformal pertama sekali diperkenalkan di Ghana pada tahun 1971 oleh seorang peneliti dari Manchester bernama Keith Hearth. Sektor informal tersebut mulai menjadi pembahasan di kalangan pengamat pembangunan setelah diterbitkan hasil laporan penelitian oleh ILO dan UNDP. Senthuraman (Soeratno, 2000), dalam bukunya yang berjudul "The Urban Informal Sector in Developing Countries" terbitan ILO 1981, memberikan definisi umum sektor informal adalah sektor ekonomi yang terdiri dari unit usaha berskala kecil yang memproduksi serta mendistribusikan barang dan jasa dengan tujuan pokok menciptakan kesempatan kerja dan pendapatan bagi dirinya masing-masing, dan dalam usahanya itu sangat dibatasi oleh faktor kapital, baik fisik maupun ketrampilan. Sektor informal yang berada di daerah pedesaan seringkali disebut sektor informal tradisional yang bergerak di bidang pertanian, sedangkan untuk sektor informal yang berada di daerah perkotaan sebagian besar bergerak dalam kegiatan pedagang kaki lima.

Menurut pendapat Bromley (Mulyanto, 2007), pedagang kaki lima (PKL) merupakan kelompok tenaga kerja yang banyak di sektor informal.
Pandangan Bromley, pekerjaan pedagang kaki lima merupakan jawaban terakhir yang berhadapan dengan proses urbanisasi yang berangkai dengan migrasi desa ke kota yang besar, pertumbuhan penduduk yang pesat, pertumbuhan kesempatan kerja yang lambat di sektor industri dan penyerapan teknologi yang padat moral, serta keberadaan tenaga kerja yang berlebihan.

Pedagang Kaki Lima (PKL) adalah termasuk usaha kecil yang berorientasi pada laba layaknya sebuah kewirausahaan. Mereka mempunyai cara tersendiri dalam mengelola usahanya agar mendapatkan keuntungan dan sekaligus menjadi manajer tunggal yang menangani usahanya mulai dari perencanaan usaha, menggerakkan usaha sekaligus mengontrol atau mengendalikan usahanya, padahal fungsi-fungsi manajemen tersebut jarang atau tidak pernah mereka dapati dari pendidikan formal (Mulyanto, 2007). Manajemen usahanya berdasarkan pada pengalaman dan alur pikir mereka yang otomatis terbentuk sendiri berdasarkan arahan ilmu manajemen pengelolaan usaha, hal inilah yang disebut learning by experience. Kemampuan manajerial memang sangat diperlukan PKL guna meningkatkan kinerja usaha mereka, selain itu motivasi juga sangat diperlukan guna memacu keinginan para PKL untuk mengembangkan usahanya. 
Di kota Ponorogo, salah satu jenis pedagang kaki lima yang mempunyai fenomena menarik adalah pedagang Angkringan. Menurut Santoso (2012), sekitar tahun 1999-an jumlah pedagang Angkringan di kota Ponorogo hanya sekitar 5 pedagang. Jumlah tersebut dari tahun ke tahun mengalami kenaikan dan sampai dengan sekarang (2012) jumlah pedagang Angkringan menjadi sekitar 29 pedagang. Mereka mayoritas bukan berasal dari kota Ponorogo melainkan dari kota-kota di wilayah Propinsi Jawa Tengah, yaitu berasal dari Kabupaten Klaten, Surakarta, Sukoharjo, dan Yogyakarta.

Pedagang Angkringan di Kota Ponorogo dapat digolongkan menjadi 3 golongan, yaitu pedagang yang mandiri, semi mandiri, dan non mandiri (Santoso, 2012). Seorang pedagang Angkringan dikatakan sebagai pedagang yang mandiri adalah mereka yang memiliki gerobak sendiri sekaligus menyiapkan makanan dan jajanan sendiri, kendati tetap dan selalu bersedia menerima makanan titipan. Pedagang Angkringan yang termasuk dalam golongan semi mandiri adalah mereka yang memiliki gerobak sendiri tetapi makanan dan jajanan dipasok oleh orang lain, biasanya oleh ketua kelompok. Sedangkan pedagang Angkringan yang termasuk dalam golongan non mandiri adalah mereka yang menyewa gerobak dan sekaligus mengambil makanan dan minuman dari ketua kelompok, sehingga sifatnya hanya menjualkan saja. Pedagang Angkringan yang termasuk golongan mandiri secara otomatis menjadi ketua kelompok, biasa disebut juragan atau bos, sedangkan pedagang Angkringan yang termasuk golongan semi mandiri dan non mandiri menjadi anggota kelompok.

Kemampuan para pedagang Angkringan di kota Ponorogo untuk mengembangkan usahanya dan bertahan dalam menghadapi persaingan usaha tidak hanya dipengaruhi oleh ketrampilan dan semangat kerja yang mereka miliki, tetapi juga sangat dipengaruhi oleh adanya jalinan solidaritas diantara mereka. Solidaritas tersebut dapat terjadi antara ketua kelompok dengan anggotanya, solidaritas antara sesama anggota kelompok, dan solidaritas anggota kelompok yang satu dengan kelompok yang lain.

Mengkaji fenomena solidaritas kelompok pedagang Angkringan di Kota Ponorogo, tentu saja tidak dapat lepas dengan teori Solidaritas telah dikenalkan oleh Emile Durkheim pada tahun 1964 melalui karyanya yang berjudul The Devision of Labour in Society. Teori tersebut menjelaskan bahwa pertumbuhan dalam pembagian kerja meningkatkan suatu perubahan dalam struktur sosial dari solidaritas mekanik ke solidaritas organik (dalam Doyle Paul Johnson, 1994). Solidaritas mekanik didasarkan pada suatu kesadaran kolektif bersama yang menunjukkan pada totalitas kepercayaankepercayaan dan sentimen-sentimen bersama yang rata-rata ada pada warga masyarakat yang sama itu. Solidaritas ini tergantung pada individu-individu yang memiliki sifat-sifat yang sama, menganut kepercayaan dan pola normatif yang sama pula. Berlawan dengan itu, solidaritas organik muncul karena pembagian kerja bertambah besar. Solidaritas ini didasarkan pada tingkat saling ketergantungan yang tinggi. Saling ketergantungan ini bertambah sebagai hasil dari bertambahnya spesialisasi dalam pembagian pekerjaan, yang memungkinkan dan juga menggairahkan bertambahnya perbedaan di kalangan individu. Munculnya perbedaan-perbedaan di tingkat individu ini merombak kesadaran kolektif, yang pada gilirannya menjadi kurang penting lagi bagi dasar keteraturan sosial dibandingkan dengan saling ketergantungan fungsional yang bertambah antara individu-individu yang mengambil spesialisasi dan secara relatif lebih otonom sifatnya.

Lebih lanjut Durkheim menjelaskan bahwa pertumbuhan dalam pembagian kerja (dan solidaritas organik sebagai hasilnya) tidak menghancurkan kesadaran kolektif; dia hanya mengurangi arti pentingnya dalam pengaturan terperinci dalam kehidupan sehari-hari. Hal ini memberikan lebih banyak ruang untuk otonomi individu dan heterogenitas sosial, tetapi tidak harus membuat individu menjadi terpisah sama sekali dari ikatan sosial yang didasarkan pada konsensus moral. Dengan demikian, ketika jumlah penduduk, kepadatan sosial dan pembagian kerja dalam suatu sistem terjadi peningkatan, maka masyarakat akan berubah dari solidaritas mekanik menuju solidaritas organik.

\section{METODE}

Kabupaten Ponorogo merupakan salah satu kabupaten yang berada di wilayah Propinsi Jawa Timur bagian barat. Salah satu kecamatan yang ada di Kabupaten Ponorogo dan sebagai pusat pemerintahan sekaligus sebagai pusat aktifitas perekonomian adalah Kecamatan Ponorogo atau sering disebut dengan Kecamatan Kota. Di wilayah Kecamatan Kota tersebut banyak dijumpai aktifitas ekonomi sektor informal, termasuk di dalamnya pedagang kaki lima. Daya tarik perkembangan aktifitas ekonomi di Kota Ponorogo telah banyak menarik perhatian dari masyarakat dari luar Kabupaten Ponorogo untuk membuka usaha di Kota Ponorogo. Salah satu aktifitas ekonomi sektor informal yang banyak dimasuki oleh masyarakat pendatang adalah pedagang Angkringan. Aktifitas pedagang Angkringan di Kota Ponorogo telah menunjukkan perkembangan yang cukup signifikan dari tahun ke tahun. Sedangkan berdasarkan lokasi usaha, lokasi usaha yang mereka pilih cukup menyebar, yaitu hampir di seluruh jalan protokol yang ada di wilayah Kecamatan Kota.

Terkait dengan informasi atau data yang dibutuhkan dalam penelitian ini maka teknik pengumpulan data dengan menggunakan wawancara mendalam terhadap subyek penelitian dan dilengkapi dengan observasi atau pengamatan secara langsung di lokasi usaha Angkringan. Informan penelitian ditetapkan dengan menggunakan teknik Purposive Sampling, yaitu pemilihan sampel berdasarkan karakteristik tertentu yang dianggap mempunyai sangkut paut dengan karakteristik populasi yang sudah diketahui sebelumnya. Adapun karakteristik 
dan jumlah informan dalam penelitian ini adalah: a) Pedagang golongan mandiri sebanyak 4 informan, yaitu Winarno, Windardi, Sandiyo, dan Slamet; b) Pedagang golongan semi mandiri sebanyak 3 informan, yaitu Rianto, Agus Wahyudi, dan Tanto; dan c) Pedagang golongan non mandiri sebanyak 4 informan, yaitu Hebi, Muhadi, Memet, dan Yusnito.

Teknik analisis data pada dasarnya berproses pada bentuk Induksi-Interpretasi-Konseptualisasi. Induksi merupakan tahap awal dalam pengumpulan dan penyajian data yang diperoleh dari lapangan. Data dikumpulkan dan dianalisis setiap meninggalkan lapangan. Interpretasi Data merupakan upaya yang dilakukan oleh peneliti untuk mengurai informasi atau data yang disampaikan oleh informan termasuk makna yang tersembunyi dibalik informasi atau data tersebut. Konseptualisasi merupakan upaya yang dilakukan peneliti bersama dengan para informan dalam memberikan pernyataan tentang yang sebenarnya dialami oleh para informan termasuk terhadap makna tersembunyi dibalik informasi atau data yang disampaikan oleh para informan.

Aktifitas analisis data dilakukan di lapangan dan bahkan bersamaan dengan proses pengumpulan data dalam wawancara mendalam. Reduksi data dan sajian data merupakan dua komponen dalam analisis data. Penarikan kesimpulan dilakukan jika pengumpulan data dianggap cukup memadai dan dianggap selesai. Jika terjadi kesimpulan yang dianggap kurang memadai maka diperlukan aktifitas verifikasi dengan sasaran yang lebih terfokus. Ketiga komponen aktifitas tersebut saling berinteraksi sampai diperoleh kesimpulan yang mantap. Menurut Sutopo (2002), proses analisis data tersebut dinamakan Model Analisis Interaktif.

\section{HASIL DAN PEMBAHASAN}

\section{Pedagang Angkringan}

Pedagang Angkringan dalam menjalankan usahanya mengunakan sebuah gerobak dari kayu dan pada malam hari menggunakan lampu kecil dengan bahan bakar minyak tanah (Orang Jawa menyebut lampu thinthir atau teplok) untuk penerangan. Mereka menjajakan makanannya mulai selepas sore (sekitar jam lima sore) sampai menjelang dini hari (sekitar jam satu sampai dengan jam dua malam). Biasanya pedagang Angkringan memarkir gerobaknya di trotoar jalan kemudian menutupi bagian depan dengan terpal mulai dari atap gerobak sampai ke tanah, mirip sebuah tenda. Di dalam tenda dan di setiap sisi gerobak Angkringan dipasang bangku untuk tempat tempat duduk pembeli, sedangkan disekitarnya dibersihkan dan disediakan tikar plastik bagi pembeli yang suka duduk di bawah atau lesehan.

Di dalam gerobak pada bagian kanan terdapat kompor arang untuk memanaskan air dan diatasnya terdapat tiga teko besar. Tiga teko besar tersebut sebagai ciri khas dari Angkringan dan menjadi pembeda dengan warung kopi lesehan (pedagang asli Ponorogo). Tiga teko besar tersebut satu berisi air putih yang dididihkan, satu berisi wedang jahe dan satunya lagi berisi wedang teh. Di bagian kiri ketiga teko besar tersebut, biasanya diisi dengan bungkusan nasi, lauk seperti ceker (kaki ayam), tempe dan tahu bacem serta beberapa jenis sate, seperti sate usus dan sate telur puyuh. Nasi bungkus yang disediakan biasanya disebut sego kucing, karena memang isinya relatif lebih sedikit, seperti makanan kucing, berupa nasi dengan sambal teri atau nasi dengan racikan tempe goreng. Sisi gerobak sebelah belakang (dekat dengan pedagang) biasanya digunakan untuk tempat sendok, berbagai rokok eceran, tempat gula dan kopi. Cadangan gula dan kopi, cadangan rokok dan bahan minum lainnya biasanya disimpan di dalam laci bagian atas gerobak, sementara laci kecil di bawah tumpukan makanan digunakan untuk menyimpan uang. Bagian belakang dari tempat duduk pedagang disediakan dua atau lebih ember berisi air yang digunakan untuk persediaan air bersih yang akan dimasak dan untuk mencuci gelas yang kotor.

Para pedagang Angkringan di Kota Ponorogo dalam menjalankan dan mengembangkan usahanya tidak secara terpisah atau sendiri-sendiri tetapi mereka membentuk kelompok. Satu kelompok pedagang Angkringan diketua oleh seorang ketua dan mempunyai anggota kelompok antara dua sampai dengan enam orang. Berdasarkan kepemilikan gerobak Angkringan dan penyediaan jajanan dan makanan, pedagang Angkringan di Kota Ponorogo dapat digolongkan menjadi tiga golongan, yaitu pedagang Angkringan mandiri, semi mandiri dan non mandiri (Santoso, 2012). Seorang pedagang Angkringan yang termasuk dalam golongan mandiri adalah jika mereka memiliki gerobak sendiri dan sekaligus membuat jajanan dan makanan sendiri, tetapi tetap bersedia menerima makanan titipan. Pedagang Angkringan yang termasuk dalam golongan semi mandiri adalah jika mereka memiliki gerobak sendiri tetapi makanan dan jajanan mengambil dari pedagang Angkringan golongan mandiri. Pedagang Angkringan yang termasuk dalam golongan non mandiri adalah jika mereka menyewa gerobak dan mengambil makanan dan minuman dari pedagang Angkringan golongan mandiri.

Pedagang Angkringan golongan mandiri secara otomatis menjadi ketua kelompok, sedangkan pedagang Angkringan golongan semi mandiri dan non mandiri menjadi anggota kelompok. Seorang ketua kelompok biasanya mengontrak sebuah rumah atau mempunyai rumah sendiri di Kota Ponorogo dan ditempati bersama istri dan anaknya. Di rumah tersebut, istri ketua kelompok mempunyai usaha membuat jajanan dan makanan yang akan dijual oleh suaminya (ketua kelompok) maupun yang akan dijual para anggota kelompoknya. Selain ketua kelompok bersama keluarganya, di rumah tersebut biasanya juga tinggal beberapa anggota kelompoknya yang masih belum mampu menyewa rumah atau kost sendiri.

\section{Solidaritas Pedagang Angkringan}

Perkembangan jumlah pedagang Angkringan di Kota Ponorogo dari tahun ke tahun tidak dapat dilepaskan dari adanya jalinan solidaritas di antara 
mereka. Jalinan solidaritas tersebut tidak hanya terjadi antara ketua kelompok dengan anggota kelompok, tetapi juga antara sesama anggota dalam satu kelompok dan antara kelompok yang satu dengan kelompok yang lain. Jalinan solidaritas kelompok pedagang Angkringan tersebut dapat digambarkan sebagai berikut:

Pertama, Solidaritas antara ketua kelompok dengan anggota kelompok. Solidaritas yang terjadi antara ketua kelompok dengan anggota kelompok pedagang Angkringan di Kota Ponorogo dimulai pada saat ketua kelompok berupaya untuk menambah anggotanya dengan jalan memberikan informasi, baik kepada pelanggan, teman, maupun kerabat dari daerah asalnya, terkait perkembangan usaha Angkringan dan sekaligus mengajak mereka untuk membuka usaha Angkringan di Kota Ponorogo.

Ketika sebuah kelompok pedagang Angkringan telah terbentuk, maka mulai terjalin pembagian kerja yang sudah jelas antara ketua kelompok dengan anggotanya. Ketua kelompok mempunyai wewenang untuk membuat jajanan dan makanan yang akan disajikan di Angkringan. Jajanan dan makanan tersebut selain dijual oleh ketua kelompok sendiri juga akan diambil oleh para anggota kelompoknya dan mereka berhak mengambil keuntungan dari hasil penjualan jajanan dan makanan tersebut. Jajanan dan makanan yang tidak laku dijual akan dikembalikan kepada ketua kelompok dan tidak wajib dibayar. Selain itu, jika terdapat anggota kelompok yang tidak mempunyai gerobak Angkringan dan tidak mampu untuk mengadakan sendiri, maka ketua kelompok menyewakan gerobak Angkringan kepada anggota kelompok tersebut. Adanya kejelasan pembagian kerja antara ketua dengan anggota kelompok pedagang Angkringan di Kota Ponorogo tersebut bukan berarti ketua kelompok tidak lagi membantu anggotanya dalam bidang yang lain. Ketua kelompok tetap membantu anggotanya mulai mencarikan lokasi usaha yang strategis, membantu permodalan dan menyediakan tempat tinggal.

Gambaran solidaritas antara ketua dengan anggota kelompok pedagang Angkringan tersebut, dapat lebih dijelaskan dari berbagai penuturan yang disampaikan oleh para informan penelitian, yaitu sebagai berikut:

Winarno (ketua kelompok) menyampaikan: "Saya selalu berusaha menjalin hubungan baik dan kekeluargaan dengan anggota kelompok saya dan jika saya mampu saya juga membantu mereka. Misalnya, sampai saat ini mereka yang tinggal di rumah saya di Ponorogo tidak saya tarik biaya tetapi kalau berjualan mereka mengambil jajanan dari istri saya. Saya juga mempunyai gerobak yang dijalankan oleh orang lain dan dia juga mengambil jajanan dari istri saya. Sekitar dua bulan pertama saya belum berani menarik uang sewa gerobak karena kondisi usahanya masih belum ramai. Dan sekarang karena sudah berkembang saya menarik sewa gerobak sehari Rp 3.000".

Windardi (ketua kelompok) menyampaikan: "Saya menjalin hubungan dengan anak buah saya.
Saya akan selalu membantu anak buah saya kalau mereka mengalami kesulitan, misalnya masalah modal usaha, dan lokasi atau tempat berjualan".

Sandiyo atau Pak Dji (ketua kelompok) menyampaikan: "Saya dengan anggota kelompok saya selalu menjalin hubungan kekeluargaan, karena mengingat anggota saya satu daerah, tetangga dan saudara saya. Saya saling membantu, misalnya anggota kelompok saya bisa tinggal di rumah saya dan tidak ditarik biaya, saya juga membantu modal untuk anggota yang belum mampu, dan saya juga membantu mencarikan lokasi tempat jualan dan sekaligus mencarikan ijin kepada pemilik rumah atau toko yang halaman depannya dapat ditempati untuk angkringan. Semua itu saya lakukan karena jika anggota kelompok saya jualannya laris juga akan berpengaruh pada usaha saya. Jadi saling membutuhkan dan saling menguntungkan. Dan bahkan jika ada anggota kelompok saya yang mau membuka usaha sendiri saya juga mempersilahkan, karena saya juga masih bisa mencari anggota baru dari daerah saya. Hitung-hitung juga ikut mengurangi penganguran".

Slamet (ketua kelompok) menyampaikan: "Saya menjalin hubungan dengan anak buah saya berdasarkan kepercayaan. Saya akan selalu membantu anak buah saya kalau mereka mengalami kesulitan dan menyampaikan kepada saya, misalnya masalah modal usaha, lokasi dan ijin membuka usaha, maupun masalah keuangan".

Rianto (anggota kelompok) menyampaikan: "Karena biaya hidup di perantauan besar dan untuk usaha banyak saingan (sebelumnya pernah usaha nasi goreng di Makasar), saya akhirnya pulang dan ikut saudara saya (Pak Winarno) usaha Angkringan di Ponorogo. Karena sudah mengetahui kondisi Ponorogo dan juga masih banyaknya kesempatan mengembangkan usaha Angkringan, maka pada tahun 2004 saya membuka usaha Angkringan sendiri, tetapi untuk jajanan dan makanan saya mengambil dari Pak Winarno sebagai ketua kelompok".

Hebi (anggota kelompok) menyampaikan bahwa: "Saya ditawari untuk membuka usaha Angkringan karena menurut Pak Windardi saya sudah mempunyai teman yang banyak dan nantinya akan bisa menjadi pelanggan Angkringan saya. Maka pada tahun 2010 saya memulai usaha Angkringan dan saya memilih lokasi usaha di Jalan Diponegoro (Depan BRI). Untuk ijin menempati lokasi tersebut saya dibantu oleh Pak Windardi ... Semua jajanan dan makanan saya mengambil dari Pak Windardi, sebagai ketua kelompok. Kalau gerobak saya sewa dari Pak Windardi juga, dengan biaya Rp. 3.000 per hari".

Muhadi (anggota kelompok) menyampaikan: "Ketika ngopi di Angkringannya Pak Windardi, saya ditawari untuk membuka usaha Angkringan dan menjadi anggota kelompok Pak Windardi. Maka pada tahun 2007 saya memulai usaha Angkringan dan oleh Pak Windardi dipilihkan lokasi dan sekaligus ijinnya di Jenderal Sudirman (depan SMPN 4) ... Jajanan dan makanan dari Pak Windardi, sebagai ketua 
kelompok, dan sekaligus gerobak saya sewa dengan biaya Rp. 3.000 per hari.".

Agus Wahyudi(anggotakelompok)menyampaikan: "Karena pengalaman saya ikut angkringan teman saya di Malang dan cukup laris, maka saya pingin membuka usaha Angkringan sendiri. Ketika saya dolan dan ngangkring di Ponorogo, pada waktu itu di angkringan Pak Dji (Sandiyo), setelah ngobrol dengan akrap dan lama, saya akhrinya tertarik ikut kelompok Pak Dji untuk membuka usaha Angkringan di Ponorogo. Saya mulai membuka usaha Angkringan di Ponorogo pada tahun 2001".

Tanto (anggota kelompok) menyampaikan: "Ketika pulang ke Bayat Klaten, saya ditawari oleh Pak Dji (Sandiyo), tetangga satu desa yang sudah membuka usaha warung Angkringan di kota Ponorogo, untuk ikut usaha Angkringan ke kota Ponorogo. Akhirnya sekitar tahun 2000 saya ikut Pak Dji ke kota Ponorogo. Pertama kali saya masih ikut dan membantu Pak Dji. Setelah beberapa bulan dan sudah mengenal kondisi di kota Ponorogo, saya berkeinginan untuk membuka usaha angkringan sendiri dan keinginan tersebut didukung oleh Pak Dji, bahkan saya dicarikan tempat dan sekaligus ijin kepada orang yang mempunyai halaman yang akan saya tempati'.

Memet (anggota kelompok) menyampaikan: "Setelah ngobrol dengan Pak Slamet yang membuka usaha Angkringan di depan California Karaoke, maka saya tertarik untuk mencoba membuka usaha Angkringan tersebut dan sekaligus menjadi anak buah Pak Slamet ... untuk gerobak Angkringan saya menyewa dari Pak Slamet, sehari biaya sewanya sebesar Rp. 3.000".

Yusnito (anggota kelompok) menyampaikan: "Saya pingin usaha dagang walaupun kecil-kecilan, mempunyai tempat yang menetap, dan memperoleh penghasilan harian. Pada waktu ketemu Pak Slamet, saya ditawari untuk bergabung dalam kelompok Angkringannya, dan akhirnya pada tahun 2007 saya mulai usaha Angkringan di Ponorogo ... Jajanan dan makanan saya mengambil dari Pak Slamet ditambah dengan titipan beberapa orang. Sedangkan untuk gerobak saya menyewa dari Pak Slamet dengan biaya Rp. 3.000 per hari ... Biasanya kalau saya menyampaikan permasalahan usaha angkringan akan dibantu memecahkan. Saya dan ketua kelompok biasanya ngobrol pada saat saya mengambil jajanan dan makanan, dan pada saat menyetor hasil penjualan jajanan dan makanan tersebut".

Kedua, Solidaritas antara sesama anggota dalam satu kelompok. Solidaritas dalam kelompok pedagang Angkringan di Kota Ponorogo tidak hanya terjalin antara ketua dengan anggota kelompoknya tetapi juga terjalin di antara sesama anggota kelompok. Jalinan solidaritas di antara sesama anggota kelompok tersebut adalah saling membantu jika ada permasalahan, saling menghargai sesama anggota, dan saling mematuhi kesepakatan. Saling menghargai dan mematuhi kesepakatan yang mereka buat biasanya terkait masalah lokasi berjualan. Lokasi berjualan yang mereka tempati diatur sedemikian rupa agar tidak saling berdekatan dan tidak terjadi persaingan antar sesama anggota kelompok. Adanya kesepakatan tersebut menjadikan pedagang Angkringn mampu menyebar di setiap jalan protokol yang ada di Kota Ponorogo.

Gambaran solidaritas di antara sesama anggota kelompok pedagang Angkringan tersebut dapat lebih dijelaskan dengan berbagai penuturan yang disampaikan oleh anggota kelompok, yaitu sebagai berikut:

Rianto dan Memet menyampaikan: "Tidak ada masalah, karena lokasi berjualan agak berjauhan maka tidak ada persaingan"

Agus Wahyudi menyampaikan: "Tetap saling menghormati, tidak pernah bertengkar masalah usaha, dan selalu menganggap sebagai keluarga".

Tanto menyampaikan: "Hubungannya baik-baik aja, saling membantu jika ada masalah, dan tidak saling bersaing, karena lokasi usahanya sudah sendiri-sendiri".

Yusnito menyampaikan: "Yang penting saling menghormati antara satu dengan yang lain. Kalau ada permasalahan kadang kalau mampu akan saling membantu juga".

Ketiga, Solidaritas antara kelompok yang satu dengan kelompok yang lain. Solidaritas kelompok pedagang Angkringan tidak hanya terjadi di dalam satu kelompok, tetapi juga terjadi antara kelompok yang satu dnegan kelompok yang lain. Solidaritas tersebut terkait permasalahan lokasi usaha, aturan pengambilan jajanan dan makanan, dan saling membantu dalam acara hajatan.

Solidaritas dalam penentuan lokasi usaha yang dimaksud adalah adanya perilaku saling menghormati antar kelompok dalam memilih lokasi usaha yang strategis. Pengamatan di lapangan menunjukkan bahwa setiap lokasi usaha pedagang Angkringan tidak ada yang saling berdekatan dan mampu menyebar di seluruh jalan protokol di Kota Ponorogo. Dengan terjalinnya solidaritas ini maka para pedagang Angkringan di Kota Ponorogo tidak saling bersaing tetapi bersaingnya hanya dengan warung kopi khas Ponorogo, baik warung kopi lesehan maupun permanen.

Solidaritas dalam pengambilan jajanan dan makanan biasanya terjadi jika salah satu ketua kelompok berhalangan dalam membuat jajanan dan makanan, sedangkan anggota kelompoknya tetap akan menjalankan usaha Angkringannya, maka ketua kelompok tersebut memperbolehkan anggota kelompoknya mengambil jajanan dan makanan dari ketua kelompok lain. Namun demikian, ketua kelompok yang berhalangan tersebut sudah mengarahkan kepada anggota kelompoknya untuk mengambil jajanan dan makanan pada ketua kelompok lain yang masih satu daerah.

Solidaritas pada saat ada acara hajatan terjadi jika salah satu ketua atau anggota kelompok mempunyai hajatan di daerah asalnya dan mengundang ketua atau anggota dari kelompok lain maka sudah dapat dipastikan mereka yang diundang akan meliburkan 
usaha Angkringannya untuk membantu dan menghadiri acara hajatan tersebut.

Gambaran solidaritas antara kelompok pedagang Angkringan yang satu dengan kelompok yang lain di Kota Ponorogo, dapat lebih dijelaskan dengan berbagai penuturan yang disampaikan oleh informan penelitian, yaitu sebagai berikut:

Winarno menyampaikan: "Saya dengan kelompok lain kenal baik dan saling menghargai. Jika ada yang mempunyai hajatan saling membantu dan menghadiri acara hajatan tersebut. Kalau masalah lokasi berjualan sudah ada pengertian untuk tidak saling berdekatan, supaya pembelinya tidak bingung dan tidak berebut. Saya juga mempersilahkan anak buah saya mengambil jajanan dari kelompok lain jika saya libur tidak berjualan dan istri saya tidak membuat jajanan, misalnya pada waktu saya dan keluarga pulang ke Sukoharjo. Tapi biasanya anggota kelompok saya mengambil dari ketua kelompok yang berasal dari Sukoharjo, karena sudah kenal".

Windardi menyampaikan: "Biasanya aja dan tidak saling mengganggu atau "ngrusuhi", tidak ada persaingan yang tidak sehat, dan yang penting semua usaha angkringan dapat berjalan dengan baik. Selain itu ada kelompok lain yang masih terhitung sebagai keluarga dengan saya".

Pak Dji menyampaikan: "Kalau dengan kelompok lain tetap saling menghormati. Misalnya masalah lokasi angkringan tidak saling berdekatan sehingga pembelinya tetap banyak dan jika ada pedagang dari kelompok lain yang mempunyai hajatan $d i$ daerah asalnya, misalnya temanten atau sunatan, dan kelompok saya diundang, kami akan meliburkan angkringan untuk mendatangi hajatan tersebut".

Slamet menyampaikan: "Biasanya tergantung orangnya, kalau orangnya "grapyak" (supel) biasanya hubungan dengan pedagang dari kelompok lain baik-baik aja. Yang jelas diantara pedagang pendatang selalu saling menghargai dan tidak saling menjatuhkan".

Nur H. menyampaikan: "Ada toleransi dan saling menghargai sesama pedagang Angkringan, artinya sama-sama saling mengerti dan tidak saling menjatuhkan usaha Angkringan yang lain".

Hebi menyampaikan: "Hubungan yang ada baikbaik saja. Kalau ada anggota kelompok lain minta bantuan ya akan saya bantu semampu saya, dan juga sebaliknya saya juga pernah dibantu oleh anggota kelompok lain".

Agus Wahyudi menyampaikan: "Hubungannya baik-baik saya, dan jika ada anggota kelompok lain membutuhkan bantuan maka saya akan membantu juga".

Tanto menyampaikan: "Sangat baik, buktinya ketika saya menikah (tahun 2003) tidak hanya anggota kelompok Pak Dji yang datang, tetapi dari kelompok yang lain rela meliburkan angkringan untuk mendatangi acara pernikahan saya (mbecek)".

Memet menyampaikan: "Saling menghargai, khususnya pembagian dan jarak tempat jualan diatur agar semua dapat laku”.

\section{Pola Solidaritas Pedagang Angkringan}

Berdasarkan hasil temuan di lapangan yang telah diuraikan di atas, diketahui bahwa solidaritas yang terdapat dalam kelompok pedagang Angkringan di Kota Ponorogo tidak hanya terjadi di dalam suatu kelompok saja, solidaritas antara ketua kelompok dengan anggota kelompok atau solidaritas antara sesama anggota suatu kelompok, tetapi juga terjadi antara kelompok yang satu dengan kelompok yang lain. Meminjam istilah yang disampaikan oleh Emile Durkheim, berjalannya solidaritas mekanik dan solidaritas organik pada kelompok pedagang Angkringan di Kota Ponorogo dapat dibuat "Pola Solidaritas" pada gambar 1.

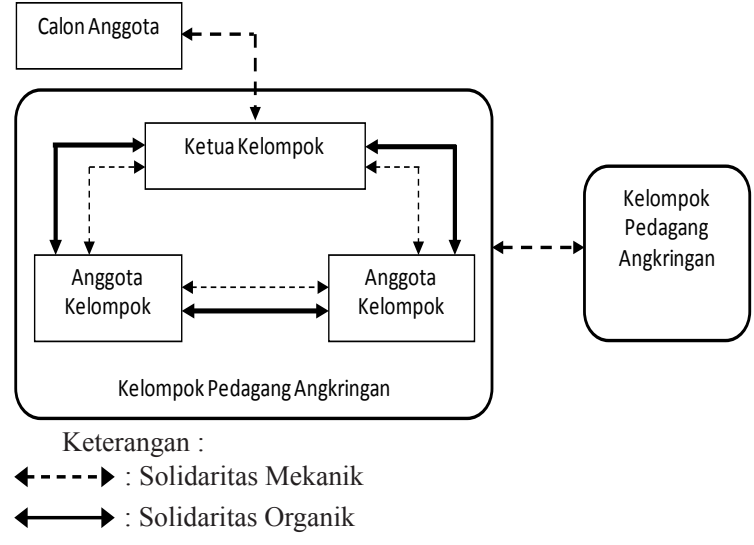

Gambar 1. Pola Solidaritas Kelompok Pedagang Angkringan di Kota Ponorogo

Pola solidaritas kelompok pedagang Angkringan di Kota Ponorogo memberikan gambaran bahwa di kelompok pedagang Angkringan telah berjalan solidaritas mekanik dan solidaritas organik, namun demikian dominasi berjalannya solidaritas tersebut berbeda-beda. Perbedaan dominasi tersebut dapat dijelaskan sebagai berikut:

Pertama, Solidaritas antara ketua kelompok dengan anggota kelompok lebih didominasi oleh solidaritas organik karena berjalannya usaha kelompok Angkringan dalam setiap hari sangat dipengaruhi oleh kepatuhan terhadap pembagian kerja dan aturan kelompok yang telah disepakati bersama. Solidaritas mekanik antara ketua kelompok dengan anggota kelompok, baik dalam bentuk bantuan pemilihan lokasi usaha yang strategis, bantuan modal usaha, penyediaan tempat tinggal, maupun saling membantu dalan acara hajatan, hanya berjalan pada saat anggota kelompok tersebut tidak mampu mengusahakannya sendiri dan lebih bersifat tidak terus menerus.

Kedua, Solidaritas ketua kelompok dalam memberikan informasi tentang peluang usaha kepada teman, saudara, atau tetangga di daerah asalnya dan berusaha mengajak mereka untuk membuka usaha Angkringan di Kota Ponorogo termasuk dalam solidaritas mekanik karena lebih menekankan pada unsur kepercayaan dan unsur kedaerahan yang sama antara pemberi informasi dengan penerima informasi.

Ketiga, Solidaritas antar sesama anggota dalam satu kelompok lebih didominasi oleh jenis solidaritas 
organik karena dalam setiap berjualan mereka saling mematuhi kesepakatan yang telah buat khususnya terkait lokasi berjualan yang tidak saling berdekatan. Solidaritas mekanik antar sesama anggota kelompok, baik berupa saling membantu permasalahan maupun bantuan dalam acara hajatan, tidak setiap hari terjadi atau bersifat isidental.

Keempat, Solidaritas antar kelompok pedagang Angkringan yang satu dengan kelompok yang lain lebih mengarah pada solidaritas mekanik karena dalam menjalankan usahanya mereka selalu menghormati pedagang Angkringan yang lain, yaitu dengan memilih lokasi usaha yang tidak saling berdekatan sehingga tidak saling berebut pembeli maupun lokasi usaha yang strategis. Solidaritas mekanik yang lain adalah berbentuk bersedia meliburkan usaha Angkringannya untuk menghadiri undangan hajatan seorang pedagang Angkringan dari kelompok lain. Selain itu, seorang ketua kelompok memperbolehkan anggota kelompoknya mengambil jajanan dan makanan dari ketua kelompok lain pada saat ketua kelompok tersebut tidak memproduksi jajanan dan makanan karena ada acara kepentingan keluarga. Biasanya ketua kelompok tersebut sudah mengarahkan anggota kelompoknya untuk mengambil jajanan dan makanan pada ketua kelompok lain tertentu, yaitu ketua kelompok yang masih satu daerah asal.

Pola solidaritas kelompok pedagang Angkringan di Kota Ponorogo tersebut di atas sesuai dengan yang dijelaskan oleh Emile Durkheim (dalam Doyle Paul Johnson, 1994) bahwa pertumbuhan dalam pembagian kerja (solidaritas organik) tidak menghancurkan kesadaran kolektif (solidaritas mekanik) tetapi hanya mengurangi arti pentingnya dalam pengaturan terperinci dalam kehidupan seharihari. Solidaritas organik memberikan lebih banyak ruang untuk otonomi individu dan heterogenitas sosial, tetapi tidak harus membuat individu menjadi terpisah sama sekali dari ikatan sosial yang didasarkan pada konsensus moral.

Temuan penelitian pola solidaritas kelompok pedagang Angkringan ini juga sesuai dengan dengan hasil penelitian Granovetter (dalam Damsar, 1997), yang menyatakan bahwa kuatnya suatu ikatan jaringan memudahkan seseorang untuk mengetahui ketersediaan pekerjaan. Dalam hal ini, jaringan sosial juga memainkan peranan penting dalam berimigrasi dan kewiraswastaan imigran. Jaringan tersebut merupakan ikatan antar pribadi yang mengikat para migran melalui kekerabatan, persahabatan, komunitas asal yang sama. Selain itu, kebanyakan kewiraswastaan yang terjadi pada komunitas migran dimudahkan oleh jaringan dari ikatan dalam upaya saling tolong menolong, sirkulasi modal, bantuan dalam hubungan dengan birokrasi.

\section{SIMPULAN}

Jalinan solidaritas yang terjadi pada kelompok pedagang Angkringan di Kota Ponorogo berbentuk: a) Solidaritas antara ketua kelompok dengan para anggotanya (termasuk calon anggota), b) Solidiritas antara sesama anggota dalam satu kelompok, dan c) Solidaritas antara kelompok yang satu dengan kelompok yang lain.

Solidaritas antara ketua kelompok dengan calon anggota kelompok lebih mengarah pada solidaritas mekanik. Ketua kelompok memberikan informasi tentang peluang usaha kepada calon anggota barunya dan berusaha mengajak mereka untuk membuka usaha Angkringan di Kota Ponorogo. Mereka lebih menekankan pada unsur kepercayaan dan unsur kedaerahan yang sama antara pemberi informasi dengan penerima informasi. Sedangkan solidaritas antara ketua kelompok dengan anggota kelompok lebih didominasi oleh solidaritas organik karena berjalannya usaha kelompok Angkringan dalam setiap hari sangat dipengaruhi oleh kepatuhan terhadap pembagian kerja dan aturan kelompok yang telah disepakati bersama. Solidaritas mekanik antara ketua kelompok dengan anggota kelompok, baik dalam bentuk bantuan pemilihan lokasi usaha yang strategis, bantuan modal usaha, penyediaan tempat tinggal, maupun saling membantu dalan acara hajatan, hanya berjalan pada saat anggota kelompok tersebut tidak mampu mengusahakannya sendiri dan lebih bersifat tidak terus menerus.

Solidaritas antara sesama anggota dalam satu kelompok lebih lebih didominasi oleh solidaritas organik karena dalam setiap berjualan mereka saling mematuhi kesepakatan yang telah buat khususnya terkait lokasi berjualan yang tidak saling berdekatan. Solidaritas mekanik antar sesama anggota kelompok, baik berupa saling membantu permasalahan maupun bantuan dalam acara hajatan, tidak setiap hari terjadi atau bersifat isidental.

Solidaritas antara kelompok yang satu dengan kelompok yang lain lebih mengarah pada solidaritas mekanik karena dalam menjalankan usahanya mereka selalu menghormati pedagang Angkringan yang lain, yaitu dengan memilih lokasi usaha yang tidak saling berdekatan, tidak berebut lokasi yang strategis, meliburkan udaha untuk menghadiri undangan hajatan seorang pedagang Angkringan dari kelompok lain. Selain itu, seorang ketua kelompok memperbolehkan anggota kelompoknya mengambil jajanan dan makanan dari ketua kelompok lain pada saat ketua kelompok tersebut tidak memproduksi jajanan dan makanan karena ada acara kepentingan keluarga.

Berdasarkan kesimpulan tersebut di atas, hasil penelitian ini dapat dimanfaatkan sebagai bahan masukan untuk memperkaya bahan kajian dan pengambangan bidang ilmu Sosiologi Ekonomi, khususnya masalah fenomena sektor informal dan solidaritas kelompok sektor informal. Selain itu, khususnya untuk pemerintah daerah dapat membuat kebijakan pengembangan usaha kecil yang lebih difokuskan pada pengembangan jaringan solidaritas kelompok yang akhirnya mampu menciptakan modal sosial di antara mereka.

Salah satu permasalahan yang dihadapi dalam 
pelaksanakan penelitian khususnya sektor informal atau pedagang kaki lima adalah pada saat melakukan wawancara mendalam kepada responden penelitian. Alat perekam sering tidak dapat digunakan secara efektif karena lokasi usaha di sekitar kebisingan kendaraan bermotor dan responden sering mondar mandir melayani para pembelinya. Oleh sebab itu, daya ingat peneliti dan catatan harian menjadi yang utama dalam melakukan penggalian data. Wawancara mendalam juga dapat dilakukan di tempat tinggal responden ketika mereka belum berjualan, tetapi hambatannya adalah dalam memilih waktu yang tepat karena mereka di rumah juga mempunyai berbagai kesibukan atau sedang istirahat.

\section{DAFTAR PUSTAKA}

Damsar, 1997, "Sosiologi Ekonomi ", Cetakan Pertama, Penerbit PT Raja Grafindo Persada, Jakarta.

Doyle Paul Johnson, 1994, “Teori Sosiologi Klasik dan Modern”, Diindonesiakan oleh Robert M. Z. Lawang, Penerbit PT. Gramadia Pustaka Utama, Jakarta.

Mulyanto, 2007, "Pengaruh Motivasi dan Kemampuan Manajerial Terhadap Kinerja Usaha Pedagang Kaki Lima Menetap (Suatu Survai pada Pusat Perdagangan dan Wisata Di Kota Surakarta)", dalam Jurnal BENEFIT, Volume 11, Nomor 1, Juni 2007, Fakultas Ekonomi Universitas Muhammadiyah Surabaya.
Santoso, Slamet, 2006, "Kemampuan Bertahan Pedagang Warung Hik di Kota Ponorogo (The Survival of Hik Vendors in Ponorogo)", dalam Jurnal Penelitian Humaniora (Terakreditasi), Volume 7, Nomor 2, Agustus 2006, diterbitkan oleh Lembaga Penelitian Universitas Muhammadiyah Surakarta.

Santoso, Slamet, 2007, "Peran Modal Sosial terhadap Perkembangan Pedagang Kaki Lima di Ponorogo", dalam Jurnal Aspirasi (Terakreditasi), Volume XVII, Nomor 1, Juli 2007, FISIP Universitas Jember.

Santoso, Slamet. dan Jusuf Harsono, 2012, "Pola Solidaritas dan Mobilitas Kelompok Pedagang Angkringan di Kota Ponorogo", Penelitian Fundamental, dibiayai oleh Direktorat Jenderal Pendidikan Tinggi, Kementerian Pendidikan dan Kebudayaan RI, dengan Surat Penugasan Penelitian Nomor: 0046/SP2H/PP/K7/KL/ II/2012

Soekanto, Soerjono, 1990, "Sosiologi Suatu Pengantar", Penerbit PT. Raja Grafindo, Jakarta.

Soeratno, 2000, "Analisa Sektor Informal : Studi Kasus Pedagang Angkringan di Gondokusuman Yogyakarta", Jurnal OPTIMUM, Volume 1 Nomor 1 September 2000, Yogyakarta.

Sutopo, 2002, "Penelitian Kualitatif", Penerbit Sebelas Maret University Press, Surakarta. 